\title{
INFLUENCE OF OLIVE CAKE LEVEL IN SHEEP RATION WITHOUT OR WITH UREA ON GROWING LAMBS PERFORMANCE
}

\author{
G.E. Aboul-Fotouh ${ }^{1}$; M. $\operatorname{Kamel}^{1}$ and H. $\operatorname{Rady}^{2}$ \\ ${ }^{1}$ Animal Production Dept., Faculty of Agriculture, Fayoum University, Egypt. \\ ${ }^{2}$ Ministry of Higher Education, Egypt.
}

SUMMARY

$\mathrm{T}$ wo feeding trials were conducted using Ossimi ram lambs averaging $22 \mathrm{Kg}$ for 150 and 90 days for trials $1 \& 2$, respectively. In each trial, 20 lambs were assigned to form equal groups. In trial one, olive cake levels $(0,15,20 \& 25 \%)$ were used replacing clover hay forming four dietary treatments. In trial two, differences were only with ensiling olive cake with urea for 21 days. Feed intake, animals' body weight gain and feed conversion were obtained; also, a simple economic evaluation was obtained. Results of trial one showed that :1- Feed intake was insignificant different between the tested groups.2- The inclusion of crude olive cake in the ration up to $25 \%$ did not affect lambs body gain significantly.3- Feed conversion showed insignificant differences regarding DM, TDN, SV and DE and significant differences regarding DCP. The DCP/gain $(\mathrm{g} / \mathrm{Kg})$, tended to be lower with olive cake containing rations especially that contained $25 \%$ olive cake compared to the control ration. 4- The economic evaluation showed that olive cake rations resulted in lower feed cost $/ \mathrm{kg}$ gain. The $25 \%$ olive cake ration reduced feed cost $/ \mathrm{kg}$ gain by about $13.5 \%$. Results of trial two showed that: 1 - Animals performance was not affected significantly by the use of urea-treated olive cake rations compared to the control. 2- Feed intake was not affected significantly as comparing urea-treated olive cake rations with the control. However, with urea-treated olive cake tended to improve as the level of olive cake increased in the ration reflecting the effect of increasing its nitrogen content through ensiling. 3- Feed conversion was not affected significantly regarding DM, TDN, SV and DE/gain. But DCP/gain showed significantly lower values with olive cake rations that ensiled with $4 \%$ urea for 21 days before feeding. 4- The economic evaluation showed that the cost price $/ \mathrm{kg}$ gain was nearly similar for all rations with differences, not more than $3 \%$.

Keywords: Feed intake, daily gain, feed conversion, lambs and olive cake.

\section{INTRODUCTION}

There is a significant increase in the demand for animal protein due to the increase in human population. On the other hand, feed supplies has risen but at a lower rate than that needed. Such trend resulted in shortage in feedstuffs. Therefore, the greatest technical and managerial problem in Egypt is the provision of adequate nutrients to the existing animal population (Aboul-Fotouh et al., 2013). The total area of olives tended to increase up to 117 thousand feddan in 2004 year, $70 \%$ of it produce olive fruits with a total production of about 315 thousand tons. About $20 \%$ of total cultivated area is situated in Fayoum Governorate (EAS, 2004). Mediterranean countries produce $98 \%$ of the world olive oil. Olive oil production in 2009 was almost twice (2.91 million tons) as that of 1995 (1.65 million tons) (FAO, 2010). FAO (1985) reported that olive by-products could be used as alternative feeds for ruminants. Nefzaoui (1997) indicated that it could be used as fuel, fertilizers and chemical products. Abarghoeilet al. (2011), showed that the spilte use of olive cake as a feed in diets of ruminants is limited. In Egypt, Hathout et al. (1977), Khamis et al. (1989), El- Sayed et al. (1996), Fayed et al. (1999), Youssef \& Fayed (2001) and Youssef et al. (2001) cleared that olive by-products could be used as a feed ingredient with reasonable level especially for small ruminants. Olive by-products differ greatly due to the technology used for oil extraction and the nature of olive by-product (Nefzaoui, 1997) as well as the varieties cultivated.

Therefore, the present study aimed to investigate the effect of crude olive cake level in the ration alone and with urea supplement on feed intake, lambs daily gain and feed conversion of the experimental rations. Where a simple economic evaluation of the tested rations was considered. 


\section{MATERIALS AND METHODS}

The present study was carried out at the Experimental Station of Seds, Animal Production Research Institute, Agricultural Research Centre, Ministry of Agriculture, Egypt. Chemical analysis were conducted at Anim. Prod. Dept., Fac. Agric., Fayoum Univ., Fayoum Governorate, A.R.E. Lambs performance was tested using different levels of olive cake in the ration (without treatment in feeding trial one and with urea- treatment in the second one .

\section{Feeding trials:}

\section{Trial one:}

Twenty Ossimi ram lambs weighing $21.8 \mathrm{Kg}$ in average were randomly assigned to four equal groups in order to study the effect of replacing clover hay partially by olive cake on lambs performance, daily gain, feed intake and feed conversions as well as simple economic evaluations were conducted.

Animals were fed in groups on rations presented in Table (1), forming four experimental dietary groups ( 5 animals each). The trial was extended for 150 days. Rations were offered twice daily, and fresh water was available all time.

Table (1). Ingredients of the tested rations (olive cake levels), trial one.

\begin{tabular}{lcccc}
\hline Item & \multicolumn{4}{c}{ Ration } \\
\cline { 2 - 5 } & $0 \%$ OC & $15 \%$ OC & $20 \%$ OC & $25 \%$ OC \\
\hline Concentrate mixture (CM) & 60 & 60 & 60 & 60 \\
Clover hay (CH) & 40 & 25 & 20 & 15 \\
${ }^{1}$ Olive cake (OC) & 0 & 15 & 20 & 25 \\
\hline
\end{tabular}

${ }^{l}$ Crude, residue of mechanical extraction of oil, after a period of air drying .

\section{Trial two:}

Twenty Ossimi ram lambs weighing $21.9 \mathrm{Kg}$ on average were randomly assigned to four equal groups in order to study the effect of replacing clover hay partially by urea- treated olive cake on lambs performance daily gain, feed intake and feed conversion as well as a simple economic evaluation was conducted. Animals were fed in groups on rations presented in Table (2), forming four experimental dietary groups (5 animals each). The trial was lasted for 90 days. Rations were offered twice daily, and fresh water was available all time.

In both trials animals were fed at a rate of $4 \%$ of their body weight, on DM basis. Feeds tested cover the nutritional requirements of growing lambs with surplus (NRC, 1985).

Table (2). Ingredients of the tested rations (urea-Treated olive cake-(UOC)), trial two.

\begin{tabular}{lcccc}
\hline Item & \multicolumn{4}{c}{ Ration } \\
\cline { 2 - 5 } & $0 \%$ OC & $15 \%$ OC & $20 \%$ OC & $25 \%$ OC \\
\hline Concentrate mixture (CM). & 60 & 60 & 60 & 60 \\
Clover hay (CH). & 40 & 25 & 20 & 15 \\
Urea-treated olive cake (UOC) & 0 & 15 & 20 & 25 \\
\hline
\end{tabular}

Feeding value of the tested rations (SV \%, TDN\%, DE (Mcal) and DCP\%) in Tables (3) and( 4 )were according Aboul -Fotouh et al .(2013).

Table (3). Nutritive values of the rations containing crude olive cake at different levels (trial one).

\begin{tabular}{lccccc}
\hline Item & \multicolumn{5}{c}{ Rations } \\
\cline { 2 - 5 } & $0 \%$ OC & $15 \%$ OC & $20 \%$ OC & $25 \%$ OC & \pm SE \\
\hline TDN, \% & 64.09 & 63.26 & 66.27 & 61.56 & 3.61 \\
SV, \% & 55.53 & 55.28 & 56.98 & 54.02 & 3.58 \\
DE, M cal/kg & 2.83 & 2.77 & 2.90 & 2.69 & 0.16 \\
DCP, \% & $12.06^{\mathrm{a}}$ & $10.52^{\mathrm{b}}$ & $11.00^{\mathrm{ab}}$ & $9.99^{\mathrm{b}}$ & 0.56 \\
\hline
\end{tabular}

$T D N$, Total digestibility nutrients; $S V$, Starch value; DE, Digestible energy;

$D C P$, Digestible crude protein.. OC, Olive cake and SE, Standard error. 
Table (4). Nutritive value of rations at different levels of $4 \%$ urea treated crude olive cake.

\begin{tabular}{|c|c|c|c|c|c|}
\hline \multirow[t]{2}{*}{ Item } & \multicolumn{4}{|c|}{ Rations } & \multirow[b]{2}{*}{$\pm \mathrm{SE}$} \\
\hline & $0 \% \mathrm{OC}$ & $15 \% \mathrm{OC}$ & $20 \%$ OC & $25 \%$ OC & \\
\hline TDN, $\%$ & 64.09 & 63.93 & 65.07 & 67.18 & 1.95 \\
\hline $\mathrm{SV}, \%$ & 55.53 & 56.16 & 57.59 & 59.88 & 1.93 \\
\hline $\mathrm{DE}, \mathrm{M} \mathrm{cal} / \mathrm{kg}$ & 2.83 & 2.77 & 2.81 & 2.99 & 0.12 \\
\hline DCP, \% & $12.06^{\mathrm{A}}$ & $9.49^{\mathrm{B}}$ & $9.09^{\mathrm{B}}$ & $9.41^{\mathrm{B}}$ & 0.42 \\
\hline
\end{tabular}

-TDN, total digestibility nutrients; $S V$, starch value; $D E$, digestible energy;

$D C P$, digestible crude protein.--OC, olive cake; SE, standard error.

Rations feed intake in feeding trials: It was estimated as $\mathrm{g} / \mathrm{kg}$, \%of body weight, per metabolic body size regarding the intake as DM, TDN, SV, DE and DCP.

Feed conversion in feeding trials: It was calculated and expressed in terms of DM (kg), TDN (Kg), SV $(\mathrm{kg}), \mathrm{DE}(\mathrm{Mcal})$ and DCP $(\mathrm{g})$ required to produce $\mathrm{Kg}$ gain of lambs.

Economic evaluation: It was calculated considering that the price of ton for concentrate mixture, clover hay, olive cake were LE 950, 540, 200 respectively.

\section{Statistical analysis:}

The completely randomized design was used for analysis, the least significant difference (LSD) was used when treatments effects were significant (Steel and Torrie, 1980).

\section{RESULTS AND DISCUSSION}

\section{Trial one (untreated olive cake rations):}

The effect of different crude olive cake levels in the ration on Ossimi lambs growth performance is presented in Table (5).

Table (5). Growth performance of Ossimi lambs as affected by different levels of crude olive cake in the ration.

\begin{tabular}{lccccc}
\hline Item & \multicolumn{5}{c}{ Rations } \\
\cline { 2 - 5 } & $0 \%$ OC & $15 \%$ OC & $20 \%$ OC & $25 \%$ OC & SE \\
\hline Body weight, kg: & 22.00 & 21.80 & 21.80 & 21.70 & 2.00 \\
Average initial wt., kg & 45.70 & 46.10 & 45.30 & 46.00 & 1.86 \\
Average final wt., kg & 23.70 & 24.30 & 23.50 & 24.50 & 1.36 \\
Total gain, kg & 157.80 & 161.80 & 156.40 & 161.60 & 8.56 \\
Daily gain, gm &
\end{tabular}

-All comparisons were insignificant. -OC, olive cake. SE, standard error of the means

It was observed that the inclusion of crude olive cake in the ration up to $25 \%$ did not affect lambs body gain significantly. The insignificant differences were also pointed out by Giouze lgiannis et al (1978), Nefzaoui \& Ksaier (1981), Aboaysha et al (1982) and Omer et al (1995) using olive cake levels up to $35 \%$. Feed intake results (Table 6), did not show any significant differences (DM, TDN, SV, DE and DCP). Such results may be due to that all groups (treatments) tested were fed in a similar percentage of body weight.

Feed conversion (Table 7) showed insignificant differences regarding energy intake (TDN, SV\& DE) and DM per $\mathrm{kg}$ gain. It showed significant differences regard DCP conversion. Generally as the level of crude olive cake increased in the ration the $\mathrm{DCP} / \mathrm{kg}$ gain reduced (i.e. improved). Such results are not expected, as it was reported that as the level of crude olive cake increased in the ration as feed conversion values increased (i.e. gain to the worst). Giouze Lgiannis et al. (1978); Accardi et al. (1979), Razzaque et al (1982) stated the negative relationship between crude olive cake and intake/ kg gain. 
Table (6). Feed intake as affected by rations differing in crude olive cake level.

\begin{tabular}{|c|c|c|c|c|c|}
\hline \multirow[t]{2}{*}{ Item } & \multicolumn{5}{|c|}{ Rations } \\
\hline & $0 \% \mathrm{OC}$ & $15 \% \mathrm{OC}$ & $20 \% \mathrm{OC}$ & $25 \% \mathrm{OC}$ & SE \\
\hline \multicolumn{6}{|c|}{$\%$ of body weight: } \\
\hline DM & 4.00 & 4.00 & 4.00 & 4.00 & \\
\hline TDN & 2.56 & 2.53 & 2.65 & 2.46 & \\
\hline SV & 2.22 & 2.21 & 2.28 & 2.16 & \\
\hline $\mathrm{DE}$ & 11.32 & 11.08 & 11.60 & 10.76 & \\
\hline DCP & 0.48 & 0.42 & 0.44 & 0.40 & \\
\hline \multicolumn{6}{|c|}{ Per kg W $\mathrm{W}^{0.75}$ : } \\
\hline DM, g & 101.78 & 95.09 & 95.29 & 95.86 & 1.89 \\
\hline TDN, g & 65.23 & 60.15 & 63.15 & 59.04 & 1.19 \\
\hline $\mathrm{SV}, \mathrm{g}$ & 56.52 & 52.57 & 54.30 & 51.78 & 1.04 \\
\hline DE, Kcal & 288.04 & 263.42 & 276.34 & 257.88 & 10.02 \\
\hline $\mathrm{DCP}, \mathrm{g}$ & 12.27 & 10.01 & 10.48 & 9.58 & 0.50 \\
\hline
\end{tabular}

-DM, dry mater; TDN, total digestible nutrients; SV, starch value; DE, digestible energy\& DCP, digestible crude protein. -OC, olive cake. SE, standard error of the means.

Table (7). Feed conversion and economical evaluation of Ossimi lambs as affected in the ration with different levels of olive cake.

\begin{tabular}{|c|c|c|c|c|c|}
\hline \multirow[t]{2}{*}{ Item } & \multicolumn{5}{|c|}{ Rations } \\
\hline & $0 \% \mathrm{OC}$ & $15 \% \mathrm{OC}$ & $20 \% \mathrm{OC}$ & $25 \% \mathrm{OC}$ & SE \\
\hline \multicolumn{6}{|l|}{ Feed conversion: } \\
\hline DM/gain, $\mathrm{kg} / \mathrm{kg}$ & 8.9 & 8.2 & 7.9 & 8.2 & 0.2 \\
\hline TDN/gain, kg/kg & 5.7 & 5.4 & 5.0 & 5.0 & 0.2 \\
\hline $\mathrm{SV} /$ gain, $\mathrm{kg} / \mathrm{kg}$ & 5.0 & 4.7 & 4.4 & 4.4 & 0.1 \\
\hline $\mathrm{DE}, \mathrm{M} \mathrm{cal} / \mathrm{kg}$ & 25.2 & 23.8 & 21.9 & 21.9 & 0.2 \\
\hline $\mathrm{DCP}, \mathrm{g} / \mathrm{kg}$ & $1074.2^{\mathrm{A}}$ & $903.6^{\mathrm{B}}$ & $831.9^{\mathrm{BC}}$ & $816.2^{\mathrm{C}}$ & 26.2 \\
\hline \multicolumn{6}{|l|}{ Economic evaluation: } \\
\hline Air dry intake $\mathrm{kg} / \mathrm{kg}$ gain & 9.82 & 9.10 & 8.76 & 9.00 & \\
\hline Relative feed cost, L.E/kg gain $\%$ & 100 & 89.10 & 87.80 & 86.50 & \\
\hline
\end{tabular}

The economic evaluation (Table 7) was in favor of the ration contained $25 \%$ olive crude cake followed by both 20 and $15 \%$ crude olive cake then the control regarding relative $\%$ of feed price $/ \mathrm{kg}$ gain. Such trend was also observed regarding the levels used in the present study by El-Shorafa and Faqih (1982) and Khamis et al. (1989).

Trial two (urea treated olive cake ration).

The effect of different urea-treated crude olive cake levels in the ration on Ossimi lambs growth performance are presented in Table (8).

Table (8). Growth performance of Ossimi lambs as effects by rations with different urea-treated olive cake levels.

\begin{tabular}{lccccc}
\hline Item & \multicolumn{5}{c}{ Rations } \\
\cline { 2 - 5 } & 0\% OC & $15 \%$ OC & $20 \%$ OC & $25 \%$ OC & SE \\
\hline Body weight, kg: & 22.00 & 22.00 & 21.80 & 21.80 & 1.79 \\
Average initial wt., kg & 36.00 & 34.00 & 34.00 & 35.10 & 1.55 \\
Average final wt., kg & 14.00 & 12.00 & 12.20 & 13.30 & 1.26 \\
Total gain, kg & 155.00 & 133.40 & 135.60 & 147.80 & 14.59 \\
Daily gain, gm &
\end{tabular}

-OC, urea treated olive cake. - SE, standard error of the means 
Insignificant differences were obtained when urea treated olive cake level increased in the ration. However, the control tended to show better performance, as the level of urea- treated OC increased in the ration as animals performance improved. The difference between $25 \%$ urea treated olive cake rations and the control did not exceed 5\%. Such trend may be due to the increase in N level due to urea treatment to a limit that enhances rumen activity. Barth et al. (1974) reported improvement in feed digestibility when urea-N in the ration increased up to $36 \%$ of the total $-\mathrm{N}$. Nefzaoui et al. (1983) reported improvement in retained-N by about 2.7 urea with $3 \% \mathrm{NH} 3$ in exhausted olive cake ensiled with ammonia.

Feed intake as affected by rations differing in urea-treated olive cake level is presented in Table (9). Data on feed intake as $\%$ of body weight tended to show nearly similar trend to that in lambs performance.

Table (9). Feed intake as affected by rations difference in urea-treated olive cake level.

\begin{tabular}{|c|c|c|c|c|c|}
\hline \multirow[t]{2}{*}{ Item } & \multicolumn{5}{|c|}{ Rations } \\
\hline & $0 \% \mathrm{OC}$ & $15 \% \mathrm{OC}$ & $20 \% \mathrm{OC}$ & $25 \% \mathrm{OC}$ & SE \\
\hline \multicolumn{6}{|c|}{$\%$ of body weight } \\
\hline DM & 4.00 & 3.60 & 3.75 & 4.00 & \\
\hline TDN & 2.56 & 2.30 & 2.44 & 2.69 & \\
\hline SV & 2.22 & 2.02 & 2.16 & 2.40 & \\
\hline $\mathrm{DE}$ & 11.32 & 9.97 & 10.53 & 11.96 & \\
\hline DCP & 0.48 & 0.34 & 0.34 & 0.38 & \\
\hline \multicolumn{6}{|c|}{ Per kg W $\mathrm{W}^{0.75}$ : } \\
\hline DM, g & 91.67 & 81.92 & 85.23 & 91.11 & 2.06 \\
\hline TDN, g & 58.75 & 52.38 & 55.42 & 61.21 & 1.36 \\
\hline $\mathrm{SV}, \mathrm{g}$ & 50.92 & 46.00 & 49.10 & 54.56 & 1.20 \\
\hline DE, Kcal & 259.42 & 226.91 & 239.20 & 272.40 & 6.01 \\
\hline DCP, $\mathrm{g}$ & 11.06 & 7.78 & 7.75 & 8.58 & 0.25 \\
\hline
\end{tabular}

-DM, Dry mater; TDN, total digestibility nutrients; $S V$, starch value; $D E$, digestible energy\& DCP, digestible crude protein. $-O C$, urea treated olive cake. - SE, standard error of the means.

Feed conversion as affected by rations differing in urea-treated olive cake level is presented in Table (10). The increase in urea treated olive cake resulted in a reduction in feed efficiency (DM, TDN, SV and DE). But improved that of protein.

Table (10). Feed conversion and economical evaluation as affected by rations differing in ureatreated olive cake level.

\begin{tabular}{|c|c|c|c|c|c|}
\hline \multirow[t]{2}{*}{ Item } & \multicolumn{5}{|c|}{ Rations } \\
\hline & $0 \% \mathrm{OC}$ & $15 \% \mathrm{OC}$ & $20 \% \mathrm{OC}$ & $25 \% \mathrm{OC}$ & SE \\
\hline \multicolumn{6}{|l|}{ Feed conversion } \\
\hline DM/gain, $\mathrm{kg} / \mathrm{kg}$ & 7.10 & 7.23 & 7.36 & 7.28 & 0.50 \\
\hline TDN/gain, kg/kg & 4.55 & 4.63 & 4.79 & 4.89 & 0.32 \\
\hline $\mathrm{SV} / \mathrm{gain}, \mathrm{kg} / \mathrm{kg}$ & 3.94 & 4.06 & 4.24 & 4.36 & 0.28 \\
\hline $\mathrm{DE}, \mathrm{M} \mathrm{cal} / \mathrm{kg}$ & 20.08 & 20.04 & 20.66 & 21.77 & 1.28 \\
\hline DCP, $g / k g$ & $856.13^{\mathrm{A}}$ & $686.66^{\mathrm{B}}$ & $668.88^{\mathrm{B}}$ & $685.39^{\mathrm{B}}$ & 49.94 \\
\hline \multicolumn{6}{|l|}{ Economic evaluation: } \\
\hline Air dry intake $\mathrm{kg} / \mathrm{kg}$ gain & 7.87 & 8.06 & 8.21 & 8.13 & \\
\hline Relative feed cost, L.E/kg gain\% & 100 & 101.83 & 98.66 & 97.05 & \\
\hline
\end{tabular}

The economic evaluation (Table 10) showed that the differences in price / $\mathrm{kg}$ gain were nearly similar (about 2-3\%). However the $25 \%$ urea-treated olive cake is slightly more economic than the other rations. Nearly similar trend was observed with rations containing untreated olive pulp (22\% level) by Abou El- 
Nasr (1985). Also, Omer et al (1995) reported that replacing $20 \%$ of barley with olive cake was economically feasible.

\section{CONCLUSION}

Such findings may suggest the use of $25 \%$ olive cake ration especially that of untreated one with no adverse effect on lamb's performance.

\section{REFERENCES}

Abarghoei, M.; Y. Rouzbehan and D. Alipour (2011). Nutritive value and silage characteristics of whole and partly stoned olive cakes treated with molasses. J. Agr. Sci. Tech., 13:709-716.

Aboaysha, A.M.; F.E. Omar and M.A. Razzaque (1982). Olive oil cak as animal Feed.C.Use of olive oil cake supplemented with soybean seeds in the rations of growing Barbary lambs. Libyan J. Agric., 11:69-74.

Abou El-Nasr, H. M. (1985). A study on the possibilities of using desert agricultural by products in feeding live stock. Ph. Thesis, Fac. Agric. Cairo Univ., Egypt.

Aboul-Fotouh, G.E.; M. Kamel; H. Rady and H. Mahfouz (2013) Effect of olive cake level in sheep ration without or with urea or yeast on digestibility coefficients and nutritive value .Egyptian $\mathrm{J}$. Nutrition and Feeds 16(2) Special Issue 225- 233

Accardi, F; G. Leto; P. Giacconne, and M. L. Alicata (1979). Sanas vergine di oliva. Indagine Sulla compozition chimica, digeribilta ed effeto nutritivo su agnelli. Zoot. Nutri. Anim., 5:233-238.

Barth, K.M.; J.A Corrick; P.E. Shumway and Coleman, S.W. (1974). Effects of level of urea and of urea plus limestone on $\mathrm{N}$ metabolism of corn silage-based rations by cattle. J. Anim. Sci. 38:687

EAS. (2004). Agriculture Statistics. Economic Affairs Sector, Ministry of Agric. \& Land Reclamation. Dokki, Giza, ARE.

El-Sayed, E.L.; S. Shehata and F. Abou Amo (1996). Evaluation of olive pulp in complete rations for sheep in western desert of Egypt. Menofia J.Agric. Res., 21:12-15.

El- Shorafa, W.M. and A.M. Faqih (1982). Performance and carcass of Awassi male lambs fed dried poultry litter and sodium hydroxide treated olive pulp. Symp. The utilization of N Conventional Feedstuffs in Animal Feed. Amman, November.

Fayed, A.M.; H.S. Khamis and A. A. Fahmy (1999). Olive by-products silage as non-conventional feed ingredients for sheep in the north western coastal of Egypt. Egyptian Proceeding of the $7^{\text {th }}$ Scientific Conference on Animal Nutrition (Ruminants, Poultry and Fish). 19-21 October, 1999, El-Arish, Egypt. Part 1. Egyptian. J. Nutr and feeds, 1999, 2: (Special Issue): 233-241.

FAO (1985). Food and Agriculture Organization of the United Nation, Rom.

FAO (2010). Food and Agriculture Organization of the United Nation, Rom.

Giouze Lgiannis, A.; K.Tsklidi and I. Katanos (1978). The olive cake meal in the feeding of fattening lambs. Agric. Res. 2: 223-233, (In Greek, English summary).

Hathout, M.K.; I.M. Soliman; A. Al-Belaazi and S.M. Atrallah (1977). Use of sheep concentrates mixture containing olive pulp for fattening of lambs. Agric. Res. Rev., 55:97-108.

Khamis, H.S; H.M. El Shaer; M.F. Farid; A.S. Shalaby, and O.A. Salem (1989). Utilization of date seeds and olive pulp as supplementary feed for lactating ewes in Sinai. Proc. The $3{ }^{\text {rd }}$ Egyptian-British Conf. Animal, Fish and Poultry Prod., Alex., Egypt

Nefzaoui, A. (1997). Olive Tree By-products. Ministry of Agric. Tunisia.

Nefzaoui, A. and H. Ksaier (1981). Utilisation de la pulpe d'olive comme alimen de sauvegarde. Séminiare International sur la Valorisation des sous produits d 1 'olivier. Monastir, Tunisi. December 1981; 65-66.

Nefzaoui, A.; P.H.Hellings and M.Vanbelle (1983). Ensiling olive pulp with ammonia. Effects on voluntary intake and digestibility measured among sheep. In $34^{\text {th }}$ Annual Meeting of the EAAP Study Commission, Madrid, 3-6 October. p199.

Omer, J. M. A.; L. Gavoret and J. M. Abo Omar (1995). Utilization of olive cake in fattening rations of Awassi lambs. Review de Medecine Veterinaire. 146:273-293.

NRC. (1985). Nutrient requirements of sheep ( $6^{\text {th }}$ Ed.) National academy of sciences, National Research Council, Washington, D.C. 
Razzaque, M. A.; A.M. Aboaysha and F.E.Omar (1982). Olive oil cake as animal feed. Use of olive oil cake supplemented with urea in the rations of growing lambs nutrition Libyan.J. Agric., 11:61-69

Steel, R.G.D. and J.H. Torrie (1980). Principles and Procedures of Statistical. $2^{\text {nd }}$ ed. Mc Grow-Hill Book Co. Inc., London. UK.

Youssef, K.M. and A.M. Fayed (2001). Utilization of some organic wastes as feed supplement for growing goats under desert condition. Egyptian J. Nutr. and Feeds 4:91.

Youssef, K.M.; A.M. Fayed and H.S. Khamis (2001). Productive and reproductive performance of ewes and does fed non conventional rations based on olive pulp in Sinai. Egyptian J. Nutr. and feeds 4 (Special Issues): 591.

\title{
تأثير مستوى تفل الزيتون فى العليقة بدون أو مع المعاملة باليوريا على أداء الحملان النامية .
}

\author{
جمال الاين أبو الفتوح أحمد1 و ممدوح كامل1 و حسن راضى²

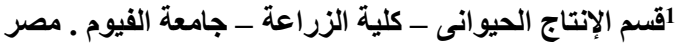

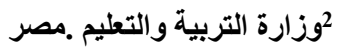

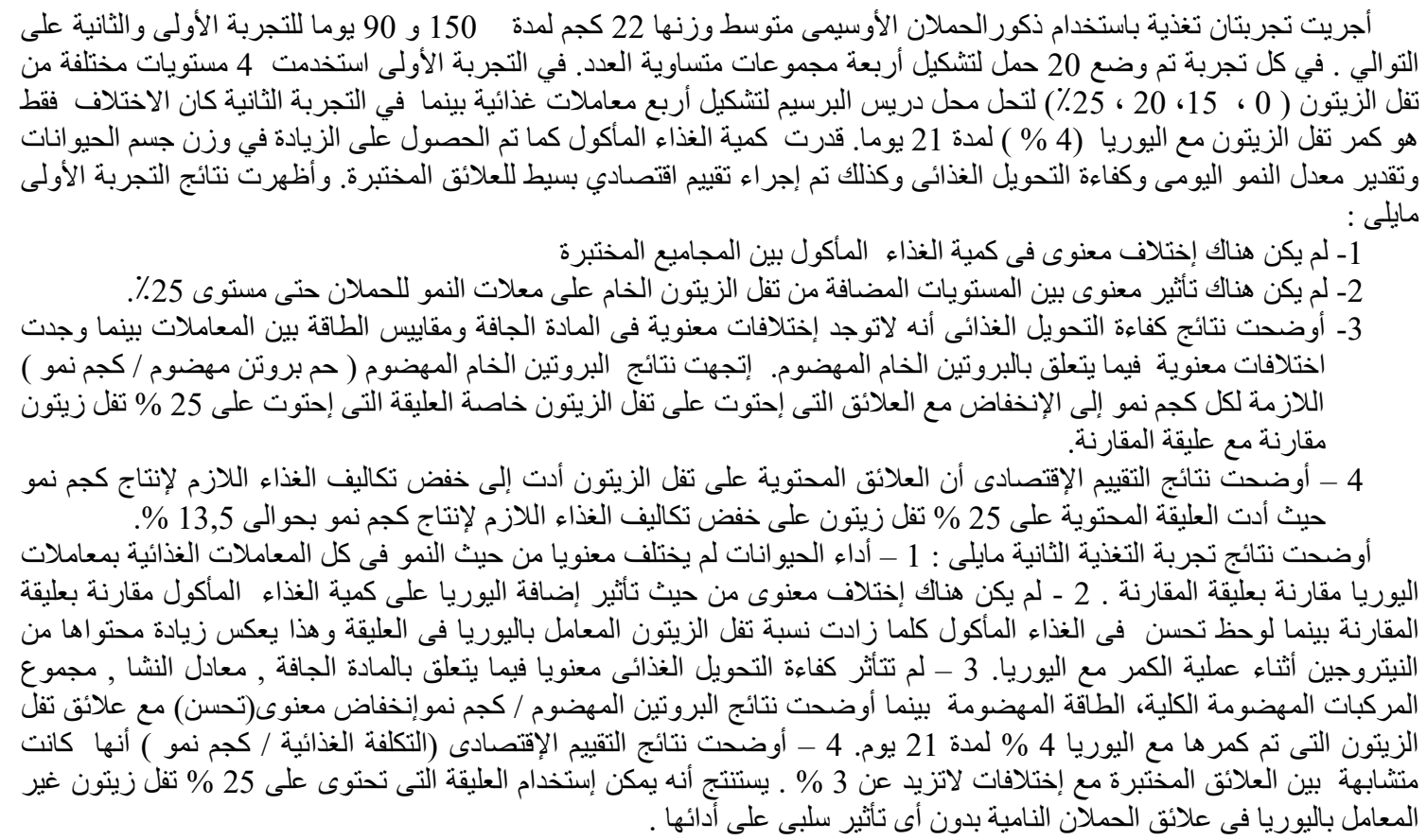

